Human Rights and Global Governance 
PENNSYLVANIA STUDIES IN HUMAN RIGHTS

Bert B. Lockwood, Series Editor

A complete list of books in the series is available from the publisher. 


\section{Human Rights and Global Governance}

Power Politics Meets International Justice

\section{William H. Meyer}

\section{$\overline{\text { PENN }}$}

UNIVERSITY OF PENNSYLVANIA PRESS

PHILADELPHIA 
Copyright $\odot 2020$ University of Pennsylvania Press

All rights reserved. Except for brief quotations used for purposes of review or scholarly citation, none of this book may be reproduced in any form by any means without written permission from the publisher.

Published by

University of Pennsylvania Press

Philadelphia, Pennsylvania 19104-4112

www.upenn.edu/pennpress

Printed in the United States of America on acid-free paper

$\begin{array}{llllllllll}10 & 9 & 8 & 7 & 6 & 5 & 4 & 3 & 2 & 1\end{array}$

Library of Congress Cataloging-in-Publication Data

Names: Meyer, William H., author.

Title: Human rights and global governance : power politics meets international justice / William H. Meyer.

Other titles: Pennsylvania studies in human rights.

Description: 1st edition. | Philadelphia : University of Pennsylvania

Press, [2020] | Series: Pennsylvania studies in human rights | Includes bibliographical references and index.

Identifiers: LCCN 2019021368 | ISBN 9780812251760 (hardcover)

Subjects: LCSH: Human rights-International cooperation-Case studies. |

International law and human rights. | International organization. |

International relations. | International cooperation. | Human rights. |

World politics.

Classification: LCC JZ1318 .M48 2020 | DDC 323-dc23

LC record available at https://lccn.loc.gov/2019021368 